\title{
ON THE CHOICE OF PROGRAMS TO CONTROL ROCKET MOTION ALONG A BALLISTIC TRAJECTORY
}

\author{
Institute of Technical Mechanics \\ of the National Academy of Sciences of Ukraine and the State Space Agency of Ukraine \\ 15 Leshko-Popel St., Dnipro 49005, Ukraine; e-mail: office.itm@nas.gov.ua
}

This paper formulates the complex problem of co-optimization of the design parameters, trajectory parameters, and control programs of a single-stage rocket with a solid-propellant sustainer engine at the initial design stage. The problem is formulated as an optimal control problem with constraints in the form of equalities and differential constraints. The parameters to be optimized are the basic design parameters of the rocket and the trajectory parameters that determine rocket motion control programs. In the proposed approach, the control programs (time variation of the pitch) in different portions of the trajectory are formed as polynomials, which reduces the optimal control problem considered to a nonlinear programming problem with constraints in the form of equalities and differential constraints. The solution of the complex problem formulated in this paper allows one to determine motion control programs optimal in a given class of functions and advisable values of the rocket design parameters at the initial design stage.

Keywords controlled rocket, mathematical model, design parameters, trajectory parameters, control program, initial design stage, solid-propellant rocket engine.

1. Degtyarev A.V. Rocketry: Problems and Prospects (in Russian). Selected scientific and technical publications. Dnipropetrovsk: ART-PRESS, 2014. $420 \mathrm{pp}$

2. Mishin V. P., Bezverby V. K., Pankratov B. M. et al. Basics of Flying Vehicle Design (Transport Systems) (in Russian): manual for technical universities. Moscow: Mashinostroyeniye, 1985. $360 \mathrm{pp}$.

3. Shcheverov D. N. Pilotless Flying Vehicle Design (in Russian). Noscow: Mashinostroyeniye, 1978. 264 pp

4. Sinyukov A. M.,.Volkov L. I., Lvov A. I.,Shishkevich A. M. Solid-Propellant Ballistic Rocket (in Russian). Moscow: Voenizdat, 1972. $511 \mathrm{pp}$

5. Varfolomeev V. I. Ballistic Rocket Design and Test (in Russian). Moscow: Voenizdat, 1970. 392 pp.

6. Vinogradov B. A., Grushchansky V. A., Dovgodush S. I. et al. Complex System Efficiency. Dynamic Models (in Russian). Moscow: Nauka, 1989. 285 pp.

7. Ilichev A. V., VolkovV. D., Grushchansky V. A. Efficiency of Complex System Design Elements (in Russian). Moscow: Vysshaya Shkola, 1982. $280 \mathrm{pp}$.

8. Krotov V. F., Gurman V. I. Optimal Control: Methods and Problems (in Russian). Moscow: Nauka, 1973. $446 \mathrm{pp}$.

9. Pontryagin L. S., Boltyansky V. G., Gamkrelidze R. V, Mishchenko E. F. Mathematical Theory of Optimal Processes (in Russian). Moscow: Nauka, 1969. 385 pp.

10. Tarasov E. V. Algorithm of Flying Vehicle Optimal Design (in Russian). Moscow: Mashinostroyeniye, 1970. $364 \mathrm{pp}$.

11. Alpatov A. P., Senkin V.S. Complex problem of optimization of the basic design parameters and motion control programs of space rockets (in Russian). Tekhnicheskaya Mekhanika. 2011. No. 4. Pp. 98-113.

12. Alpatov A. P., Senkin V.S. Methodic support for selecting an aspect, optimization of design parameters and control in-flight programs for launch vehicle (in Russian). Tekhnicheskaya Mekhanika. 2013. No. 4. Pp. 146161

13. Senkin V.S. Superlight launch vehicle design parameter optimization (in Russian). Tekhnicheskaya Mekhanika. 2009. No. 1. Pp. 80-88.

14. Senkin V.S. Controlled rocket flight control program optimization and sustainer engine propulsion optimization (in Russian). Tekhnicheskaya Mekhanika. 2000. No. 1. Pp. 46-50.

15. Siutkina-Doronina S. $V$. On the optimization of the design parameters and control programs of a solidpropellant rocket (in Russian). Aviatsionno-Kosmicheskaya Tekhnika i Tekhnologiya. 2017. No. 2 (137). Pp. 44-59.

16. Lebedev A. A., Gerasyuta N. F. Rocket Ballistics (in Russian). Moscow: Mashinostroyeniye, 1970. 244 pp.

17. Razumev V. F., Kovalev B. K. Basics of Solid-Propellant Ballistic Rocket Design (in Russian). Moscow: Mashinostroyeniye, 1976. $356 \mathrm{pp}$.

18. Erokhin B. T. Theoretical Foundations of Solid-Propellant Rocket Engine Design (in Russian). Moscow: Mashinostroyeniye, 1982. 206 pp.

19. Abugov D. I., Bobylev V. M. Solid-Propellant Rocket Engine Theory and Design (in Russian). Moscow: Mashinostroyeniye, 1987. $272 \mathrm{pp}$.

20. Shishkov A. A. Solid-Propellant Rocket Engine Gas Dynamics (in Russian). Moscow: Mashinostroyeniye, 
1974. $156 \mathrm{pp}$.

21. Senkin V. S. Complex problem of superlight launch vehicle design parameter and control program optimization (in Russian). Tekhnicheskaya Mekhanika. 2012. No. 2. Pp.106-121. 